J. Perinat. Med. 17 (1989) 469

\section{Prolonged rupture of the fetal membranes and neonatal outcome}

Ian G. Verber ${ }^{1}$, J. Malcolm Pearce ${ }^{2}$, Linda C. New ${ }^{3}$, Patricia A. Hamilton ${ }^{1}$, and E. Graham Davies ${ }^{1}$

${ }^{1}$ Departments of Child Health, and ${ }^{2}$ Obstetrics and the ${ }^{3}$ Public Health Laboratory, St Georges Hospital, London, U.K.

\section{Introduction}

Prolonged rupture of the fetal membranes (PROM), that is rupture for more than 24 hours prior to delivery, has long been recognised as an important cause of maternal and perinatal morbidity and mortality $[1,8]$. However it has also been recognised that much of the increased mortality in the presence of PROM is due to its association with prematurity [4], and to the introduction of infection by vaginal examination during the latent period [10]. There is now broad agreement amongst obstetricians that following preterm rupture of the membranes an expectant policy is safe [13]. Protocols for the management of the neonate following PROM vary greatly from centre to centre and may have been influenced by earlier studies that were uncontrolled for prematurity and in which the occurence of infection was high [7, 14]. We have therefore reviewed the results of our protocol for the management of babies born after PROM with particular reference to infection and mortality.

\section{Patients}

The subjects of the study were all the mothers and babies delivered following PROM in a two year period. During this period the standard management was as follows.

\subsection{Obstetric practice}

Rupture of the membranes was confirmed by the sight of amniotic fluid issuing from the cervix and by the characteristic smell at sterile speculum

\section{Curriculum vitae}

Dr. IAN Verber is a Mancunian and a graduate of the University of Wales. He became a member of the Royal Colleges of Physicians of the United Kingdom in 1980. He has worked in Neonatal Units in London, Manchester, and Melbourne Australia. He was Lecturer in Child

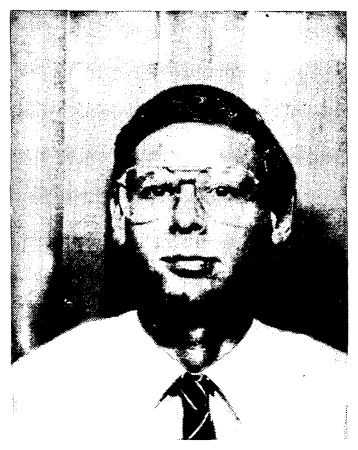

Health at St George's Hospital Medical School, University of London. He has published papers on neonatal and urinary tract infections. He is now Consultant Paediatrician in Darlington, Co Curham, U.K.

examination. For mothers presenting at term a high vaginal swab was sent for culture and if labour did not ensue within the next twelve hours it was usually induced.

Following preterm rupture without clinically evident signs of chorioamnionitis an amniocentesis was performed and the amniotic fluid sent for microscopy and culture. If organisms were present on microscopy and the gestational age was greater than 28 weeks the patient was delivered. The mothers did not receive antibiotics antenatally. Before 28 weeks gestation antibiotics were commenced if organisms were present. In these patients, and in all mothers without organisms on amniocentesis, conservative treatment was pursued with close monitoring to detect clinical amnionitis. 


\subsection{Paediatric practice}

Throughout 1986/7 the intended practice was that all babies born after $24 \mathrm{hrs}$ rupture of the membranes had a deep ear swab, cerebrospinal fluid (CSF), and blood taken for culture and a chest X-ray performed. Antibiotics were then commenced (Penicillin 50,000 $\mu / \mathrm{Kg}$ bd; Gentamicin $2.5 \mathrm{mg} / \mathrm{Kg} \mathrm{bd}$ ). These were discontinued after $48 \mathrm{hrs}$ if the baby had no clinical evedence of infection and the blood and CSF cultures were sterile. In symptomatic babies, where deep culture results were negative antibiotic therapy was continued with changes, if necessary, to cover any potential pathogens isolated from the deep ear swab.

\section{Methods}

Using the computerised medical records system used in the obstetric department the accurate retrospective identification of all babies delivered more than $24 \mathrm{hrs}$ after rupture of the membranes for a two year period was obtained. The chest $\mathrm{X}$-ray was reviewed without knowledge of the bacterial or clinical findings. The results of blood, CSF, and deep ear swab culture together with that of a maternal high vaginal swab (if available) were obtained from the bacteriology files. The blood and CSF cultures were classified as sterile, contaminated or pathogenic according to the microbiologists report. The presence of potential pathogens in high vaginal and deep ear swabs was noted. Finally the discharge summary was obtained and a diagnosis reached after considering clinical, radiological and bacteriological features, and autopsy findings if applicable.

In order to compare these findings to those of babies with early onset infection but without PROM a list of all babies born during the same two year period with positive blood cultures taken in the first $48 \mathrm{hrs}$ of life was obtained and their bacteriological, radiological and clinical findings reviewed.

\section{Results}

In the two year period there were 6066 live born babies and 40 stillbirths following 5972 pregnancies. Exclusions - In 18 cases it was impossible to identify accurately the time of membrane rupture. One, born at 24 weeks gestation was ven- tilated for eight days for what radiologically was thought to be a pneumonia and Bacterioides $s p$. was isolated from the blood after five days culture. No other baby in this group had a positive culture.

\subsection{Babies born following PROM}

There were 204 mothers (3.4\%) who had rupture of the membranes more than 24 hours prior to the delivery of 208 liveborn and three stillborn babies. None of the stillbirths had a positive post mortem blood culture. One hundred and nineteen babies were term and 89 preterm including all seven pairs of twins.

Table I groups the babies by birthweight and shows the number of babies that had blood and CSF cultured. There is a statistically significant association between low birth weight and PROM. All babies who were cultured received antibiotics. Those babies born following PROM who did not have blood cultures taken had been inadvertantly missed from the protocol and did not receive antibiotics. No baby was deliberately included or excluded from the protocol because of evidence of infection in the mother.

Blood cultures: Forty seven blood cultures were performed in term babies. Commensal organisms grew in two blood cultures (one bottle out of each pair). Both babies had a normal chest Xray and clinical course. The other 45 cultures were all sterile. Seventy nine preterm babies had a blood culture. Pathogens were grown in three - two Escherichia coli and one $\beta$ haemolytic streptococcus group B. All three babies died. In the latter case the septicaemia was thought to be the cause of death while in the other two cases it may have been contributory (though autopsy did not suggest that this was the major cause of death.) Details of these three babies are included in table II. Five preterm babies in addition grew commensal organisms. One of these babies had hyaline membrane disease, one died of bronchopulmonary dysplasia at 91 days and the other three had normal clinical courses.

CSF cultures: Twenty two CSF cultures were performed in term babies and 54 in preterms; none showed an increased cell count and all were sterile on culture.

Amniotic fluid, high vaginal swab, and ear swab cultures: Of 82 mothers who had preterm rupture of the membrane 25 did not have an amniocen- 
Table I. Occurence of PROM and investigation performed grouped according to birth weight

\begin{tabular}{lccccccc}
\hline $\begin{array}{l}\text { Birth wt } \\
\text { (grams) }\end{array}$ & $<1000$ & $\begin{array}{l}1001- \\
1500\end{array}$ & $\begin{array}{l}1501- \\
2000\end{array}$ & $\begin{array}{l}2001- \\
2500\end{array}$ & $\begin{array}{l}2501- \\
4000\end{array}$ & $>4000$ & Total \\
\hline $\begin{array}{l}\text { Total born } \\
\text { No. with prom }\end{array}$ & 76 & 108 & 142 & 284 & 5016 & 440 & 6066 \\
$\begin{array}{l}\text { Percentage } \\
\text { Investigations }\end{array}$ & 12 & 30 & 24 & 17 & 118 & 7 & 208 \\
following PROM & 15.8 & 28 & 17 & 6 & 2.4 & 1.6 & 3.4 \\
$\begin{array}{l}\text { Blood cultured } \\
\text { CSF cultured }\end{array}$ & 12 & 30 & 22 & 12 & 50 & 1 & 127 \\
\hline
\end{tabular}

$\mathrm{N}=6066$ babies. PROM associated with low birth wt $-\chi^{2}=162(5 \mathrm{df}) \mathrm{p} \ll 0.001$

Table II. Clinical and bacteriogical features of all babies with positive blood cultures taken in first $48 \mathrm{hrs}$. $\mathrm{N}=13$

\begin{tabular}{|c|c|c|c|c|c|c|}
\hline $\begin{array}{l}\text { Membranes } \\
\text { ruptured } \\
\text { hrs }\end{array}$ & $\begin{array}{l}\text { Gest age } \\
\text { weeks }\end{array}$ & $\begin{array}{l}\text { Birth wt } \\
\text { grams }\end{array}$ & Blood culture & Swabs & Clinical diagnosis & $\begin{array}{l}\dagger=\text { day } \\
\text { of death }\end{array}$ \\
\hline 1 & 24 & 630 & Grp C strep [1] & $\mathrm{E}-/ \mathrm{V}-$ & HMD & $\dagger 127$ \\
\hline 1 & 30 & 1540 & E. coli [1] & nd & HMD/Sepsis & Survived \\
\hline 1 & 30 & 1550 & L. monocytogenes & $\mathrm{E}+/ \mathrm{V}+$ & Pneum/Mening & Survived \\
\hline 2 & 28 & 1200 & L. monocytogenes & E- & Pneum & +3 \\
\hline 3 & 40 & 3860 & Strep pneumoniae & $\mathrm{V}+$ & Mening & Survived \\
\hline 9 & 37 & 2620 & Kleb. pneumoniae & V- & Pneum/Mening & $\dagger 10$ \\
\hline 9 & 42 & 3970 & Grp B strep & $\mathrm{E}+/ \mathrm{V}-$ & Sepsis & Survived \\
\hline 12 & 38 & 2340 & Grp B strep [1] & $\mathrm{E}+/ \mathrm{V}+$ & nil & Survived \\
\hline 21 & 34 & 2540 & Grp B strep & V- & Pneum & Survived \\
\hline 23 & 38 & 2790 & Grp B strep & $\mathrm{E}+$ & Pneum/sepsis & $\dagger 1$ \\
\hline 30 & 25 & 725 & Grp B Strep & $\mathrm{V}+$ & Sepsis & $\dagger 1$ hour \\
\hline 52 & 27 & 1060 & E. coli (4 days) & $\mathrm{E}+/ \mathrm{V}+$ & HMD & +2 \\
\hline 672 & 30 & 1450 & E. coli & $\mathrm{E}+/ \mathrm{V}-$ & HMD & $\dagger 1$ \\
\hline
\end{tabular}

[1]-isolate from one culture bottle only

Isolate obtained within $48 \mathrm{hrs}$ of culture from both bottles unless stated.

HMD = hyaline membrane disease; Pneum = pneumonia; $\mathrm{PH}=$ pulmonary hypoplasia.

Sepsis $=$ septicaemia; Mening $=$ meningitis.

$\mathrm{E}(\mathrm{V})+=$ blood culture organism also isolated from deep ear (high vaginal) swab.

tesis because of supervening labour or clinically obvious choroinamnionitis. Of the 57 remaining, amniocentesis was attempted in 47 cases and 46 specimens obtained. Nine had organisms on gram stain and of these Escherichia coli was cultured from three and Group B streptococcus from four. Three of these seven pregnancies were of less than 28 weeks gestation and were managed conservatively with antibiotics. Two babies delivered within three days of rupture of the membranes and died with positive blood cultures. In the third the pregnancy continued to 33 weeks and the baby had a normal clinical course.

Eighty nine mothers had high vaginal swabs performed including 67 presenting with preterm rupture of the membranes and 86 babies had deep ear swabs performed. A comparison of the results of these cultures with each other and with 
Table III. Correlation between culture isolates following PROM; HVS v Amniotic fluid v Ear swab v Blood culture

\begin{tabular}{|c|c|c|c|c|c|c|}
\hline \multicolumn{2}{|c|}{ H.V.S. } & \multicolumn{2}{|c|}{ Ear } & \multicolumn{2}{|c|}{ Amnio } & \\
\hline Pos & $\mathrm{Neg}$ & Pos & Neg & Pos & Neg & \\
\hline 2 & 1 & 2 & 0 & 2 & 1 & Pos \\
\hline 15 & 71 & 11 & 73 & & 36 & Neg Blood \\
\hline \multicolumn{2}{|c|}{ N.S } & \multicolumn{2}{|c|}{$\mathrm{p}=0.043$} & \multicolumn{2}{|c|}{ N.S. } & Signf \\
\hline \multirow{2}{*}{\multicolumn{2}{|c|}{$\begin{array}{l}0.66 \\
0.82\end{array}$}} & \multicolumn{2}{|c|}{1.0} & \multicolumn{2}{|c|}{0.66} & Sensitivity* \\
\hline & & \multirow{2}{*}{\multicolumn{2}{|c|}{$\begin{array}{l}0.86 \\
0.15\end{array}$}} & \multicolumn{2}{|c|}{0.84} & Specificity* \\
\hline \multicolumn{2}{|c|}{0.11} & & & & & PPV* \\
\hline \multicolumn{2}{|c|}{ H.V.S } & \multicolumn{2}{|c|}{ Ear } & & & \\
\hline Pos & $\mathrm{Neg}$ & Pos & Neg & & & \\
\hline 4 & 3 & 1 & 8 & & & Pos \\
\hline 3 & 33 & & 28 & & & Neg Amnio \\
\hline \multicolumn{2}{|c|}{$\mathrm{p}=0.009$} & \multicolumn{2}{|c|}{ N.S. } & & & Signf \\
\hline
\end{tabular}

N.S. $=$ Not significant $(\mathrm{p}>0.05)$

$\mathrm{p}$ values by Fisher Exact Test $\times 2$

PPV $=$ positive predictive value.

$*=$ as predictors of positive blood cultures in the baby

the results of blood cultures on the baby is shown in table III. A positive result is one in which a pathogen was isolated. Where more than one culture result was positive in the same mother/ baby pair the pathogen isolated was identical. There was a significant association between high vaginal colonisation and amnionitis, and between ear colonisation and septicaemia in the baby but not between amnionitis and ear colonisation.

Chest X-rays: Ten babies had chest X-rays suggestive of a dignosis of pneumonia in the absence of a septicaemia. Of these six had no respiratory symptoms. Five of these survived and one died on day three of the results of asphyxia with no evidence of pneumonia at autopsy. The remaining four babies required ventilation for upto three days for what clinically was thought to be hyaline membrane disease.

\subsection{Babies without PROM}

Of 5840 babies born without PROM ten grew pathogens on blood cultures taken within 48 hours of birth. The details are included in table II.
Five babies with sterile blood cultures were delivered following a positive amniocentesis performed because of preterm rupture of the membranes. Delivery was effected within 24 hours of membrane rupture which was therefore not prolonged.

\subsection{Mortality}

Nineteen babies with prolonged rupture died and details are given in table IV. The diagnosis of pulmonary hypoplasia was confirmed at autopsy. The perinatal mortality is 75.5 per thousand and the neonatal mortality is 71.8 per thousand. There were four post-neonatal deaths. When stratifying for prematurity the mortality rates remain higher than those of babies without PROM in the 28-31 week gestation group. Table $\mathrm{V}$ compares the gestational age at rupture of membranes in those babies that survived with those that died within each maturity group. As there were different numbers of twins in these two groups they have been excluded from this table. The increased mortality in the $28-31$ week group is strongly associated with those babies whose membranes ruptured earlier in pregnancy. Of the ten babies whose membranes ruptured prior to 24 weeks gestation only four survived and all four whose membranes ruptured prior to 20 weeks died.

\section{Discussion}

\subsection{Incidence of infection}

Despite the increased potential for infection following PROM only three babies of $208(1.4 \%)$ had a proven septicaemia. This is much lower than a previously reported incidence of up to $20 \%$ infection in a series in which amniocentesis was not used to detect incipient chorioamnionitis [5] but similar to that reported in a recent large U.S. series [11] where all cases of maternal amnionitis were excluded. The risks of chorionamnionitis to fetal outcome are well recognised and early obstetric intervention has been effective in reducing fetal morbidity [13]. The finding of organisms at amniocentesis correlates well with later developement of chorionamnionitis in the afebrile mother [3] therefore inducing labour in mothers with a positive amniocentesis should reduce perinatal morbidity. In this series 14 mothers were induced following positive amniotic fluid microscopy, five of whom delivered 
Table IV. Deaths in babies following PROM

\begin{tabular}{|c|c|c|c|c|c|c|}
\hline Gestational age: - & \multicolumn{2}{|c|}{$<28$ weeks } & \multicolumn{2}{|c|}{$28-31$ weeks } & \multicolumn{2}{|l|}{$\geqslant 32$ weeks } \\
\hline Total births & \multicolumn{2}{|l|}{45} & \multicolumn{2}{|l|}{119} & \multicolumn{2}{|l|}{5902} \\
\hline Deaths & \multicolumn{2}{|l|}{20} & \multicolumn{2}{|l|}{13} & \multicolumn{2}{|l|}{12} \\
\hline Mortality per 1000 & \multicolumn{2}{|l|}{444} & \multicolumn{2}{|l|}{109} & \multicolumn{2}{|l|}{2.03} \\
\hline Babies with prom & \multicolumn{2}{|l|}{14} & \multicolumn{2}{|l|}{33} & \multicolumn{2}{|l|}{161} \\
\hline Deaths & \multicolumn{2}{|l|}{8} & \multicolumn{2}{|l|}{9} & \\
\hline Mortality per 1000 & \multicolumn{2}{|l|}{571} & \multicolumn{2}{|l|}{281} & & 12.3 \\
\hline $\mathrm{p}=$ & \multicolumn{2}{|l|}{ N.S. } & \multicolumn{2}{|l|}{$<0.025$} & $<0.05$ & $\left(\chi^{2}\right)$ \\
\hline \multirow[t]{4}{*}{ Cause of death } & HMD & $5^{*}$ & HMD & $5^{*}$ & \multirow{4}{*}{\multicolumn{2}{|c|}{ Asphx 2}} \\
\hline & PH & 1 & PH & 2 & & \\
\hline & Sepsis & $1 \dagger$ & BPD & 1 & & \\
\hline & NEC & 1 & LA & 1 & & \\
\hline \multirow[t]{4}{*}{ Blood cultures } & $*$ E. coli & 1 & $*$ E. coli & 1 & \multirow{4}{*}{\multicolumn{2}{|c|}{ Sterile 2}} \\
\hline & $\dagger$ GBS & 1 & Non path & 1 & & \\
\hline & Sterile & 6 & Sterile & 5 & & \\
\hline & & & not done & 2 & & \\
\hline
\end{tabular}

HMD = Hyaline membrane disease; $\mathrm{PH}=$ pulmonary hypoplasia; Sepsis = septicaemia; NEC = necrotising enterocolitis; BPD = bronchopulmonary dysplasia; Asphx = birth asphyxia; LA = lethal abnormality GBS = Group B streptococci; Non path = non-pathogenic organism

Table V. Deaths in singleton babies following PROM. N = 194 singleton births

\begin{tabular}{llll}
\hline Gestational age: - & $<28$ weeks & $28-31$ weeks & $\geqslant 32$ weeks \\
\hline No of deaths & 5 & 9 & 2 \\
No of survivors & 5 & 19 & 154 \\
Mean ga at birth for babies dying & 26.0 & 28.9 & 35.66 \\
& $(\mathrm{SD}=1.0)$ & $(\mathrm{SD}=.83)$ & $(\mathrm{SD}=4.04)$ \\
Mean ga at birth for survivors & 26.2 & 29.5 & 38.4 \\
& $(\mathrm{SD}=.84)$ & $(\mathrm{SD}=.93)$ & $(\mathrm{SD}=2.67)$ \\
Difference & $\mathrm{NS}$ & $\mathrm{NS}$ & $\mathrm{NS}$ \\
Mean ga at rom for babies dying & 23.6 & 21.9 & 35 \\
& $(\mathrm{SD}=3.65)$ & $(\mathrm{SD}=5.91)$ & $(\mathrm{SD}=5)$ \\
Mean ga at rom for survivors & 25.0 & 28.0 & 40.45 \\
& $(\mathrm{SD}=1.22)$ & $(\mathrm{SD}=2.35)$ & $(\mathrm{SD}=29.3)$ \\
Difference & $\mathrm{NS}$ & $\mathrm{p}<0.01$ & $\mathrm{NS}$ \\
\hline
\end{tabular}

ga $=$ gestational age; rom $=$ rupture of membranes

within 24 hours of rupture. There were two babies with positive ear swabs and these were septicaemic. The remaining 12 did not have a speticaemia or potential pathogens in the deep ear swab. The obstetric intervention prior to the colonisation of the baby may account for the decreased incidence of infection in this series.
Although the infection rate is low compared to previous reports there was still a fivefold increase in the incidence of definite infection in very low birth weight babies following PROM ( 3 of 42 babies) compared to those without PROM ( 2 of 142). Amongst babies of greater than $1500 \mathrm{~g}$ there was no tendency for increased infection 
compared with the rest of the population. ( 0 of 166 compared to 8 of 5716) Deep ear swabs are more likely to indicate potential blood pathogens than contemporaneously performed high vaginal swabs but due to the low incidence of septicaemia both have a low positive predictive value. Deep ear swabs help modify the choice of antibiotic after treatment has been commenced but the delay in obtaining the results limits their suggested use as an indication to start antibiotics [9].

\subsection{Mortality}

Of the 19 babies who died following PROM, infection ws implicated as the major cause of death in only one case compared with $20 \%$ in a much earlier series [6]. The higher mortality in babies following PROM is due either to onset of labour prior to 28 weeks or following very prolonged rupture of the membranes which is known to carry a poor prognosis [12]. However recent work [2] has shown that up to $40 \%$ of these babies can survive and expectant management should be pursued.

The two fatalities in babies born with PROM after 32 weeks gestation were from the complications of asphyxia. Although this is a significantly higher mortality figure than for babies without PROM the numbers are very small and the Apgar scores amongst the survivors does not support any association between PROM and birth asphyxia.

\begin{abstract}
In order to establish the incidence of neonatal infection following prolonged (greater than 24 hours) rupture of the fetal membranes (PROM) and assess outcome a two year retrospective study was undertaken.

The names of all babies born following PROM were obtained from the computerised obstetric record and the bacteriological results and outcome reviewed.

Of 208 babies born following PROM only three had blood cultures containing pathogens - all of whom were of less than $1500 \mathrm{~g}$ birthweight and all of whom died. This represents a fivefold increased frequency of infection for premature babies but no increased risk for full term babies. The overall incidence of infection
\end{abstract}

was much lower than in previous series and this may be due to performing amniocentesis as soon as possible following rupture and inducing labour where there was evidence of incipient chorionamnionitis. Meningitis was not associated with prolonged rupture of the membranes.

The mortality for these babies was higher than those of babies without PROM in the 28-31 week gestation group. This was strongly associated with early onset of membrane rupture and none of the babies born following membrane rupture prior to 20 weeks gestation survived. Non-infective pulmonary disease was the main cause of increased mortality.

Keywords: Amniocentesis, chorioamnionitis, fetal membranes - premature rupture, infant - newborn.

\section{Zusammenfassung}

\section{Vorzeitiger Blasensprung und neonatales Outcome} Das Management bei Neugeborenen nach vorzeitigem Blasensprung ( $>24 \mathrm{~h}$ ) variiert von Zentrum zu Zentrum, ebenso unterschiedlich sind die angegebenen Infektionsraten und Mortalitätsziffern. In der vorliegenden Arbeit berichten wir über die Ergebnisse mit unserem Vorgehen bei diesen Kindern.

Unter Benutzung eines computergestützten Datensystems wurden alle Kinder, die in einem Zeitraum von 2 Jahren nach vorzeitigen Blasensprung geboren wurden, identifiziert. Die Ergebnisse der Blutkulturen, Kulturen aus dem Liquor und tiefen Ohrabstriche sowie die Röntgenthorax-Aufnahmen der Kinder wurden zusammengestellt. Auch die Ergebnisse von Abstrichen bei der Mutter gingen in die Untersuchung ein. Die klinischen Aufzeichnungen zeigten Diagnose und Ver- lauf. Diese Daten wurden mit denen von Neugeborenen verglichen, die im gleichen Zeitabschnitt geboren wurden und ebenfalls eine früh auftretende Infektion hatten, ohne daß jedoch ein vorzeitiger Blasensprung vorlag.

204 Mütter (3.4\%) hatten einen vorzeitigen Blasensprung ( $>24 \mathrm{~h}$ ). Sie wurden von 208 Lebendgeborenen und 3 Totgeburten entbunden. In Tab. I sind die Kinder entsprechend ihrem Geburtsgewicht aufgelistet. Außerdem gehen daraus die Neugeborenen hervor, bei denen Blut- und Liquorkulturen angesetzt wurden. In drei Blutkulturen wuchsen pathogene Keime, alle drei Kinder starben. Die 76 angesetzten Liquorkulturen waren steril. Unter den 5840 Neugeborenen ohne vorzeitigen Blasensprung waren 10 , in deren Blutkulturen, die innerhalb von $48 \mathrm{~h}$ post par- 
tum abgenommen wurden, pathogene Keime wuchsen. Die Details aller 13 Kinder mit positiven Blutkulturen sind in Tab. II zusammengefaßt.

Tab. III zeigt die Ergebnisse von Fruchtwasser, hohem Vaginalabstrich, Ohrabstrich und Blutkulturen im Vergleich. 19 Kinder starben nach vorzeitigem Blasensprung (Einzelheiten siehe Tab. IV). Nach Blasensprung liegt die perinatale Mortalität bei $75.5 \%$ und die neonatale Mortalität bei $\mathbf{7 1 . 8 \%}$. Wenn man Gruppen nach dem Gestationsalter bildet, bleiben die Mortalitätsraten höher als bei Kindern ohne vorzeitigen Blasensprung mit 28-31 Schwangerschaftswochen. Tab. V vergleicht das Gestationsalter zum Zeitpunkt des Blasensprungs von den verstorbenen Kindern mit dem der Kinder, die überlebten. Die erhöhte Mortalität in der Gruppe 28-31 Schwangerschaftswochen ist streng assoziiert mit einem früh auftretenden vorzeitigen Blasensprung.
Bei nur 3 von 208 Neugeborenen (1.4\%) ließ sich eine Sepsis nachweisen, was deutlich unter den früher berichteten Zahlen liegt. Nach positivem mikroskopischen Fruchtwasserbefund wurden 14 Frauen eingeleitet, davon wurden 5 Frauen innerhalb von $24 \mathrm{~h}$ nach Blasensprung entbunden. 12 der Kinder von den 14 Frauen hatten keine Sepsis oder potentiell pathogene Keime im Ohrabstrich. Die geburtshilfliche Intervention vor möglicher Kolonisierung des Kindes könnte der Grund für die niedrige Infektionsrate sein. Immer noch ist jedoch das Infektionsrisiko von Kindern mit niedrigem Geburtsgewicht nach vorzeitigem Blasensprung fünf mal höher. Die hohe Mortalität bei Kindern nach vorzeitigem Blasensprung ist bedingt durch die Frühgeburtlichkeit und speziell assoziiert mit einem sehr frühen Blasensprung. Die Kinder starben hauptsächlich wegen repiratorischer Komplikationen, unabhängig von einer Infektion.

Schlüsselwörter: Amniozentese, Chorioamnionitis, fetale Membranen, Kind, Neugeborenes, vorzeitiger Blasensprung.

\section{Résumé}

\section{Rupture prolongée des membranes foetales et devenir neonatal}

La prise en charge des enfants nés après rupture des membranes de plus de 24 heures (PROM) est variable d'un centre à l'autre, de même que l'incidence rapportée d'infection et de mortalitée. Nous avons donc revu les résultats de notre protocole pour la prise en charge de ces enfants.

On a identifié le nom de tous les enfants nés après PROM sur une pèriode de 2 ans en se servant d'un système d'enregistrement médical informatisé. On a obtenu les résultats des hémocultures, des cultures du LCR, des cultures des écouvillonages profonds de l'oreille et des clichés thoraciques avec les résultats des cultures maternelles. On a revu l'enregistrement clinique afin d'obtenir le diagnostic et le devenir. On a comparé ces données avec celles des enfants ayant eu une infection à début précoce mais en l'absence de PROM au cours de la même pèriode de 2 ans.

204 mères $(3,4 \%)$ ont présenté une rupture des membranes de plus de 24 heures avant la naissance de 208 nouveaux-nés vivants et de 3 morts-nés. Dans le tableau III les nouveaux-nés sont groupés selon leurs poids de naissance et figure le nomgre de nouveauxnés ayant eu une hémoculture et une culture du LCR. Des germes pathogènes ont poussé à partir des hémocultures de trois enfants qui sont tous décédés. 76 cultures de LCR ont toutes été stériles. Dix des 5840 enfants nés sans PROM ont eu une croissance de germes pathogènes à partir des hémocultures effectuées au cours des 48 premières heures après la naissance. Les détails concernant les 10 nouveaux-nés ayant des hémocultures positives avec des germes pathogènes figurent dans le tableau II.

Une comparaison des résultats du liquide amniotique, des écouvillonages vaginaux profonds, des écouvillonages profonds de l'oreille et des hémocultures est donnée dans le tableau III. 19 nouveaux-nés avec rupture prolongée sont morts et les détails sont dans le tableau IV. La mortalité périnatale après PROM est de 75,5 pour mille et la mortalité néonatale est de 71,8 pur mille. Après correction en fonction de la prématurité, les taux de mortalité demeurent plus élevés que ceux des nouveaux-nés sans PROM dans le groupe des 28-31 semaines de gestation. Le tableau V compare l'âge gestationnel à la rupture des membranes chez les survivants avec celui dee ceux qui sont morts. La mortalité accrue dans le groupe des 28-31 semaines est étroitement corrélée avec les nouveaux-nés dont les membranes se sont rompues le plus tôt au cours de la grossesse.

Seuls trois des 208 nouveaux-nés $(1,4 \%)$ ont eu une septicémie prouvée ce qui est nettement inférieur à ce qui a été rapporté antérieurement. Quatorze mères ont été déclenchées à la suite d'un examen au microscope du liquide amniotique positif, 5 d'entre elles ont accouché dans les 24 heures après la rupture. Douze de ces nouveaux-nés n'avaient ni de septicémie ni de germes pathogènes potentiels dans les écouvillonages profonds de l'oreille. L'intervention obstétricale avant la colonisation de l'enfant peut rendre compte de la diminution de l'incidence de l'infection. Néanmoins, il y a encore cinq fois plus de risque d'infection chez les nouveaux-nés de faible poids de naissance nés après PROM. L mortalité plus élevée chez les nouveaux-nés après PROM est preque totalement secondaire à la prématurité et s'accompagne tout particulièrement d'une rupture très précoce des membranes. La mort est principalement secondaire à des causes respiratoires sans rapport avec l'infection.

Mots-clés: Amniocentèse, chorioamniotite, enfant, membranes foetales, nouveau-né, rupture prématurée. 


\section{References}

[1] BIRCHELl RC: Premature spontaneous rupture of the membranes. Am J Obstet Gynecol 88 (1964) 251

[2] Blott M, A Greenough: Neonatal outcome after prolonged rupture of the membranes starting in the second trimester. Arch Dis Child 63 (1988) 1146

[3] Garite JS, RK Freeman: Chorioamnionitis in preterm gestation. Am J Obstet Gynecol 59 (1982) 539

[4] Gillibrand PM: Premature rupture of the membranes and prematurity. J Obstet Gynecol $\mathrm{Br}$ Cwlth 74 (1967) 678

[5] Graham RL, LC Gilstrap, JC Hauth, S KoDACK-GARZA, DG CONASTER: Conservative management of patients with premature rupture of fetal membranes. Obstet Gynecol 59 (1982) 606

[6] Leblenz TB, LP Hellman, R Madding, A ANCTIL, SL ARJE: Double blind study of premature rupture of the membranes. Am J Obstet Gynecol 87 (1963) 218

[7] Pryles CV, NL Steg, S Nair, SS Gellis, B TeNNEY: A controlled study of the influence on the newborn of prolonged premature rupture of the amniotic membranes and/or infection in the mother. Pediatrics 31 (1963) 608

[8] Russel KP, GV ANDERson: Aggressive management of rupture of the membranes. Am J Obstet Gynecol 83 (1962) 930
[9] SCANLON J: The early detection of neonatal sepsis by examination of the liquid obtained from the external ear canal. J Pediatr 79 (1971) 247

[10] SChutte MF, PE TrefFers, GJ Kloosterman: Management of premature rupture of membranes; the risk of vaginal examination to the infant. Am J Obstet Gynecol 146 (1983) 395

[11] St. Geme JW, DL Murray, J Carter et al: Perinatal bacterial infection after prolonged rupture of amniotic membranes; an analysis of risk and management. J Pediatr 104 (1984) 606

[12] TAYLOR J, GERITE TJ: Premature rupture of membranes before fetal viability. Obstet Gynecol 64 (1984) 615

[13] VARNER MW, R Galask: Conservative management of premature rupture of membranes. Am J Obstet Gynecol 140 (1981) 39

[14] Wilson M, DH Armstrong, R Nelson, RA BoAK: Prolonged rupture of the fetal membranes: Effect on the newborn infant. Am J Dis Child 107 (1964) 138

Received August 25, 1989. Accepted November 27, 1989.

Dr Ian G. Verber

Department of Pediatrics

Darlington Memorial Hospital

Darlington

Co. Durham

DL3 6HX

U.K. 